\title{
Safranbolu Evlerinin Plan Tipolojisi ve Kullanıcı ihtiyaçları Hiyerarşisi
}

Bu makale, 1979-80 yıllarında İTÜ Mimarlık Fakültesi’nde büyük bir araştırma ekibi ile yaptığımız, Turizm Bakanlığı tarafından desteklenen "Safranbolu ve Çevresi Turistik Geliştirme Projesi” kapsamında tarafımdan yürütülen bir teze (Bulduk 1979) ve 2011-2012 yıllarında şahsen Safranbolu'da yaptı̆̆ım araştırmalara dayanmaktadır. 1979-80 yıllarındaki araştırmamız sırasında 32 binanın rölövesi yapılmıştı. Bunlara ek olarak Safranbolu Belediyesi'nden alınan 15 adet yeni rölöve ile birlikte 47 adet bina planı üzerinden bu çalışma gerçekleştirilmiştir. Henüz basılmakta olan bir kitabımda (Bayazıt 2014) yer alacak olan resim ve planlardan bazı örnekler aşağıda verilmektedir.

\section{Kentin Kısa Geçmişi}

Geçmişi Paleolitik çağlara kadar giden Safranbolu, UNESCO tarafından bir Osmanlı kenti olarak 1994 yılında Dünya Mirası olarak kabul edilmiştir. Özellikle Osmanlı döneminde Safranbolu'nun ekonomik açıdan özel bir yeri vardır. Karadeniz ticaretinin 18. yüzyıla kadar önemini sürdüren Sinop limanının Gerede ile bağlantısı olan Kuzey Anadolu Ticaret Kervan Yolu üzerinde yer alması Safranbolu'yu konaklama noktası haline getirmiştir. İstanbul-Bolu-Gerede-Tosya-Amasya-Tokat-Sivas kervan yolu Gerede'den başlayarak Safranbolu ve Kastamonu üzerinden Sinop'a varıyordu (Günay 1981, 12). Safranbolulu kent soylularının sarayla doğrudan ticari ve kültürel ilişkileri olduğu görülmektedir. Büyük kentlerle ilişki günümüzde de devam etmektedir. Bu durum özellikle İstanbul ve diğer ülkelerle olan ilişkiler nedeniyle kültürel bir zenginlik

sağlamıştır. Dışarıdan Asmazlar (Kafkasya), Kırımlılar (Rusya) gibi zengin aileler gelip Safranbolu'ya yerleşmişlerdir.

\section{Geleneksel Evlerin Özellikleri}

19. yüzyıl sonunda ve 20. yüzyıl başında sahip olduğu kapalı ev içi üretim ekonomisine dayanan ataerkil geniş aile yapısı, Safranbolu evlerinin tasarım ilkelerini etkilemiştir. Safranbolu evlerinde ekonomik ve toplumsal açıdan varlıklı, eğitimli, görgülü bireylerin yaşadığı bilinmektedir (Ulukavak 2007). Safranbolu evleri yapıldıkları sırada çevredeki ormanlardan getirilen ahşap malzeme kullanılmıştır. Geçiciliği benimsemiş ve mütevazı yaşamı seçmiş olan Safranbolulular için, ahşap bir evin 100-150 yıl yaşaması arzu edilen bir özelliktir. Anadolu'da binlerce yıldan bugüne yan yana odaların bir araya getirildiği 
köşeli ev yapı geleneği süregelmiştir (Akın 2008; Akın 1985).

"Eyvanlı ev ve geleneksel Osmanlı evini açıklarken 'iki oda ile aralarında bir açık hacimden ve bunların önünde uzanan bir saçak altından meydana gelen plan motifi', geleneksel Osmanlı evlerinin tasarımında gözlenebilen en ilginç ve sürekli özelliktir (Akın 1985, 53)'. Güneydoğu Anadolu'da özellikle kent evlerinin büyük bir çoğunluğunu oluşturan eyvanlı evler, Gaziantep, Urfa, Diyarbakır ve Mardin'de yoğunlaşmıştır. Bu dört kent dışında, coğrafi konumları gereği, iklimleri Güneydoğu Anadolu geneline göre daha az sıcak olan küçük ölçekli yerleşmelerde de, eyvanlı ev yoğunluğu vardır” (Akın 1985, 138).

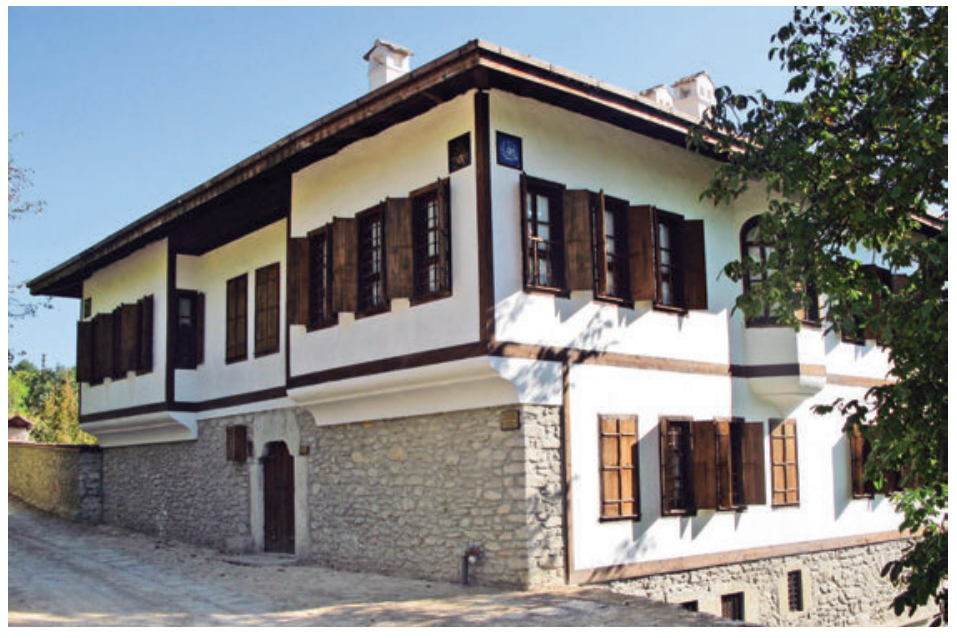

Simetri kaygisı taşımadığg söylenen geleneksel Osmanlı evinde, zorunlu olarak simetrik olan üçlü birimin bunca önem taşıması ilginçtir ve kökeninin söz konusu ev geleneğinin dışında aranmasin

Resim: 1 gerektirir.

Üçlü mekân grubunda oluşan birimin Anadolu'daki eş zamanlı benzerleri, eyvanlı evde ve kırsal yerleşmelerdeki hilanilerde en yakın biçimiyle karşımıza çıkar. Ayrıca simetrik üçlü birimin sözü edilen ve bir karşıtlıktan kaynaklanan özellikleri de geleneksel Osmanlı Evi'nde sürer. Sokağın veya parselin rastlantısal sınırlarınca belirlenen gereksinime göre biçimlenmiş ve bitişken nitelikli bir alt katın üzerinde yükselen, üst kattaki konumuyla geleneksel Osmanlı Evi'ndeki tümel biçim, hilani ve eyvanlı evi çağrıştırır (Akın 1985, 53)² (Şekil 1).

\section{Safranbolu Evlerinin Tipolojik Özellikleri}

Safranbolu Evleri de birden dörde kadar değissen oda ve eyvan sayısına sahiptir. Odalar eyvanlarla birbirlerinden ayrılırlar. Bu geniş aile yapısı içindeki çekirdek ailelere birer ayrı "yaşama birimi” verilerek tüm yaşam gereksinimlerini bu odalar içinde karşılamaları beklenmektedir. Safranbolu'da erkeklerin mekânı selamlıktır. Burası aynı zamanda iş görüşmelerinin yapıldığ 1 ve önemli misafirlerin ağırlandığı yerdir. Her evde hemen hemen bir selamlık katı ya da girişin yanında bir selamlık odası vardır. Bu kat ya da odalar özenle süslenmiştir (Resim 2-3).

Evlerin giriş katları taş duvarlarla yapılmakta ve biçimsiz arsa sınırlarına uymaktadır. Üst katlar ise ahşap karkas olarak gerçekleştirilmiştir. Zemin katlar dışa tamamıyla kapalıdır. Yaşama katları ara ve üst katlardadır. Genellikle evler zemin üzerine bir ya da iki ahşap kat olarak yapılmakta olmasına rağmen, nadiren üç ahşap katı olanlar da vardır. Ara ve üst katlarda odalar genellikle bir ya da iki yöne üçer pencerelidir. Pencereler iki yana alt kısımlarından açılabildiği gibi, tümüyle de açılabilmektedir. Pencerelerin standart
Resim: I

Hacl Hüseyinler Evi Sokak Cephesi. flikmalı ve dört eyvanlı bir ev (Bugün Valilik Konuk Evi).

Sayı 17, 2014 

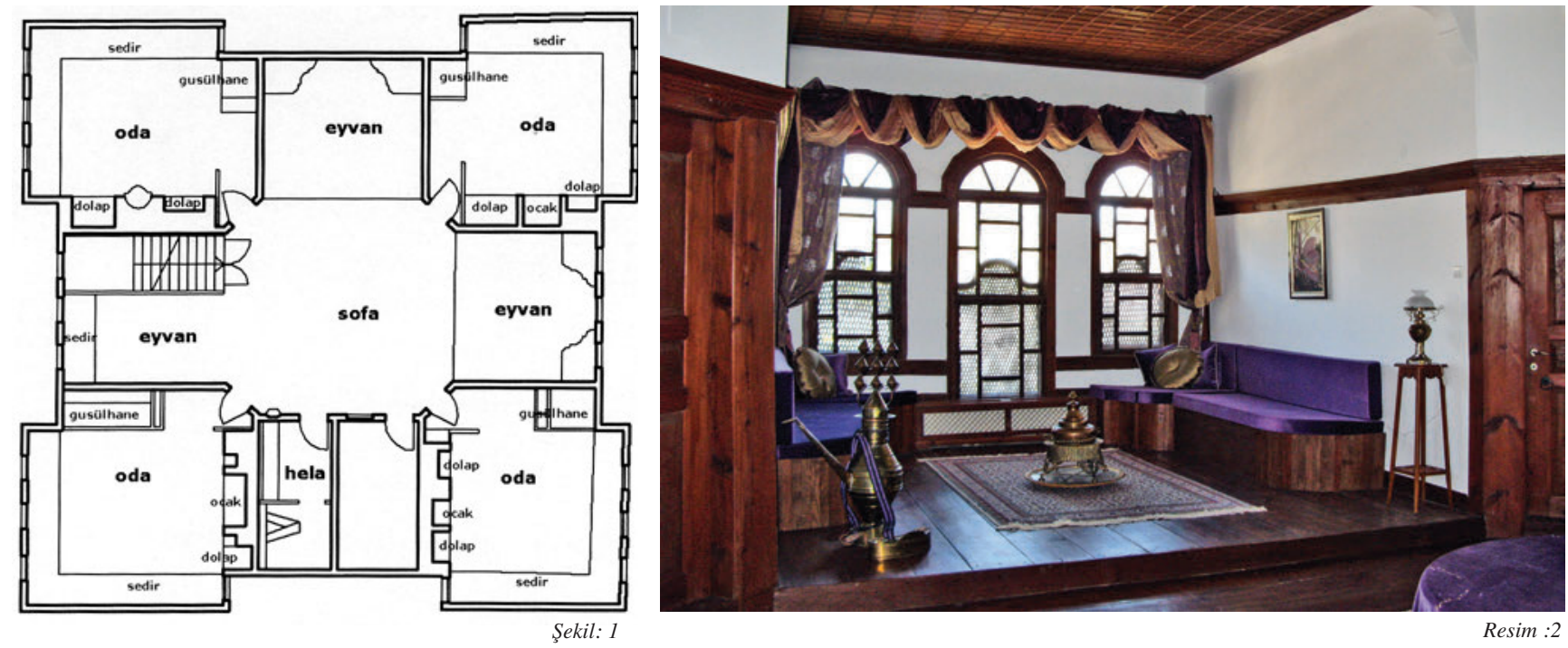

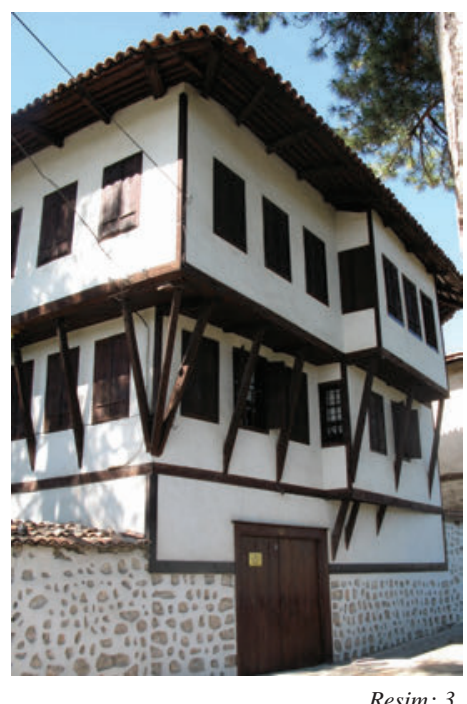

Resim: 3

Şekil: I

Bağlar'daki Gökf̧üler Konă̆l üst kat planı. Dört eyvandan birine helâ ve sandık odası yerleştirilmiş, diğerinde merdiven ve merdiven üstü eyvanı var (Bugün otel olarak kullanilmaktadır).

Resim: 2 Bağlar'daki Gökf̧üler Konă̆l Üst katındaki eyvanlardan biri günlük oturma mekânı olarak düzenlenmiştir.

Resim: 3

Ihsan Ganioğlu Evi.

Arsa planı fılkmalarla uydurulmuş bir yapı örneği. görünümde olması, ara ve üst katlardaki ahşap karkas strüktürün aralıkları ve ahşap boyutlarıyla ilgilidir. Bu nedenle bütün kentte bir ritim yaratılmıştır. Bu yapıların çatıları genellikle dört yöne eğimli kırma çatıdır.

"Odaların sayı ve şekilleri, tatbik edilecek plan tipinin meydana gelmesinde en fazla tesiri olan unsurlardır. Odalar fazla veya az olduklarına göre, plan tipi değişmekte veya inkişaf etmektedir. Bazı plan tipleri ancak muayyen oda sayıları ile elde edilebildiği gibi bazı plan tiplerinin de, fazla odalı olmalarına tahammülleri yoktur. Mesela orta sofalı planda, en az dört oda lazımdır.

Hâlbuki köșe sofalı evlerde, oda adedi iki veya üçten fazla olamaz” (Eldem 1955).

Safranbolu evlerinde Eldem'in belirttiği görüşler büyük ölçüde geçerlidir. Safranbolu evinde sofa çoğu kez birçok başka işlevi de barındıran bir mekândır. Sofa, ev içi yaşamının odağını oluşturur ve genellikle oturma mekânıdır. Tüm aile günün büyük bir bölümünü burada birlikte geçirir. Sofanın bütünüyle odalar tarafından çevrelenmesi bu mekânın ışık almasını engellediği için odalar arasında yer alan ve pencerelerle dışa bakmayı sağlayan eyvanlar kullanılır. Sofaya yönelen ve birden dörde kadar değişen eyvanların çoğu kez simetrik olarak yerleştirilmesine özen gösterilir. Safranbolu evlerinin bazılarında görülen simetrik plan şeması orta sofalı plan tipinde göze çarpar.

Safranbolu evleri, diğer Türk evlerinden plan tipolojisi açısından farklı değildir. Osmanlı Türk evlerinin planını oluşturan elemanlar

- Odalar

-Sofalar (çardaklar), eyvanlar ve diğer elemanlar

- Geçitler, aralar ve merdivenler

-Ahırlar ve taşlıklar

olarak sıralanır. Diğer bazı unsurlar kat planlarını etkilemese de evin işlevsel parçaları olan mutfak, çamaşırlık, kiler, hamam ve helâdır. Bunlar evin içine girdiği zaman sofanın bir ucuna yerleştirilir.

Genel olarak Osmanlı ev plan tipleri içinde gördüğümüz hayatlı evlerin çeşitli tiplerine ve yuvarlak orta sofalı plan tipine, Safranbolu'da çok seyrek olarak rastlanmaktadır. Safranbolu evleri genellikle ayrık düzende yapılmıştır ve bahçeleri vardır. Sofaların değişik oturma köşeleri vardır. Sofalar odaların sokak, yön ve iklim koşullarına göre 


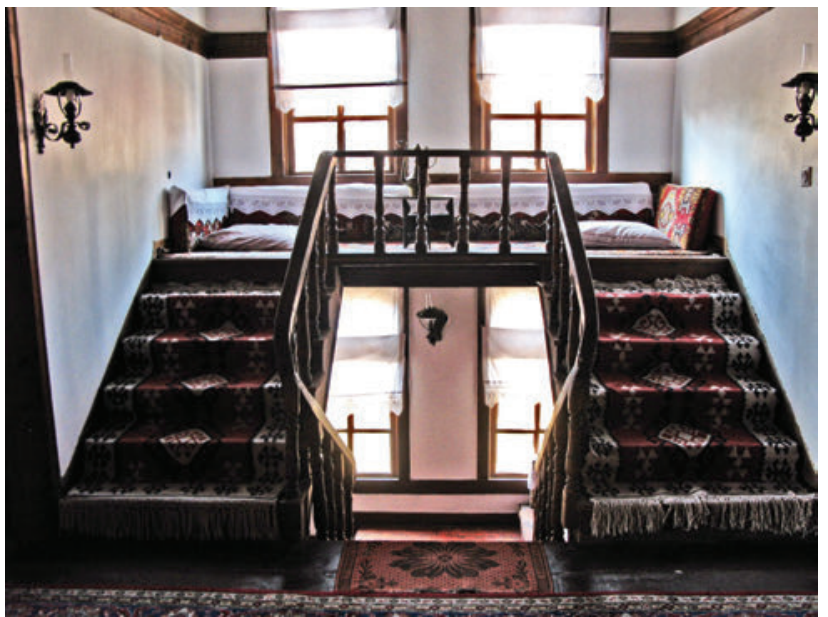

Resim: 4

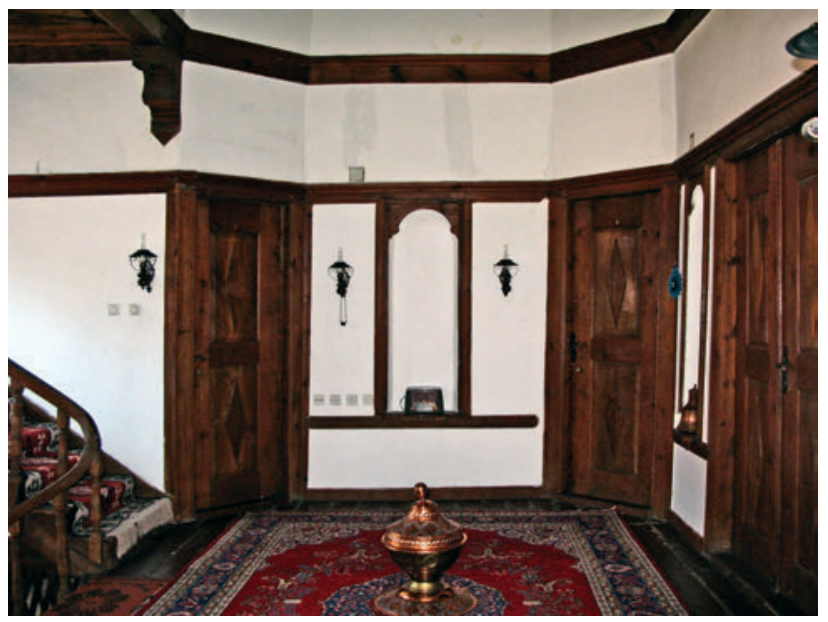

Resim: 5 odalar arasında kalan mekânlardır. Sofa her ev planında bulunur, odalar sofanın bir yanında, iki yanında veya dört köşesinde yer alırlar (Resim 4-5).

Safranbolu evlerinde sıra odalara pek rastlanmaz. Daha çok köşe odalara rastlanır ve merkezi plan tipi hâkimdir. Dış sofalı evler de, yaptığımız tespitlere göre çok fazla sayıdadır. Safranbolu evleri çevredeki plan tipolojisiyle uyum içindedir. Eldem'in kitabındaki $(1955,109,119,133,137,140)$ Bolu ev örnekleri Safranbolu evlerinin plan tipleri ile tamamıyla benzeşmektedir. Bolu'da Mühürcü Hacı Mustafa Evi, Derebeyi Mustafa Evi, Vasıf Bey Konağı, Bay Muhittin Evi, Gülerzade Evi orta sofaları ve plan tipleri ile Safranbolu evlerine benzemektedir. Arel'in $(1982,64)$ belirttiği gibi;

Toplum tabakalaşmasının iki ucu arasında kalan çevrelerde, yerel yapım özellikleri kültürel şemalarla kaynaşmış olarak varlık göstermekle birlikte, yerel gelenekler olduğu gibi değil, ama Osmanlı dönemi kültür yapısının gereklerine göre uyarlanarak kullanılır. Kültürel şemalar ise, yerel koşullara uyarlanmış olarak ve bu koşulların elverdiği ölçüde uygulanır. Gerçek Osmanlı bireşiminin ürünü olan bu ev tipleri, kaynaklarda 'Türk Evi' olarak betimlenen ev kategorisinin temsilcileridir.

Aynı konu hakkında Kuban (1995, 23), 'Filibe'de Ohrid'in görünüşü Safranbolu'ya çok benziyorsa da evlerin planları farklıdır. Bu da başat kültürel grubun biçimi görüntü olarak almışsa bile iç örgütlenmenin yerel dinamiklere bağlı olarak şekillendiğini göstermektedir' demektedir. Safranbolu evlerinin de diğer Anadolu kentlerinden farklılaşmasının aynı iç dinamiklere bağlı olduğunu göstermektedir (Şekil 2-3).

Arel'in $(1982,125)$ eserinde söz ettiği İstanbul'da Bebek'teki Köçeoğlu Yalısı planı ile (Eldem 1977, 10³ (T flemast ve egemen divanhane) Safranbolu Rauf Beyler Konağı'nda bahçedeki havuzlu köşk planı (Günay 1999, 215-231) benzerliği görüşüne varılabilir. ' $T$ ' planları ile iki yapı birbirinin aynıdır. Buradan da Safranbolu'daki yapıların zengin sahiplerinin muhtemelen İstanbul'un zenginlerinin yapılarından etkilendikleri tahmin edilebilir.
Resim: 4

Halo Mehmetler (Mehves Hanım) Konă̆ı merdiven ve merdiven üstü eyvanı (Bugün otel olarak kullanilmaktadir).

Resim: 5 Halo Mehmetler (Mehveş Hanım) Konă̆ı üst kat sofası.

Sofa bütün işlevlerin toplandığı ve dağıldığı bir merkezdir. Bu nedenle sofa ucundaki eyvan da günlük yaşam için kullanılır. Eyvanda sedir ya da bir seki yer alır. Günlük

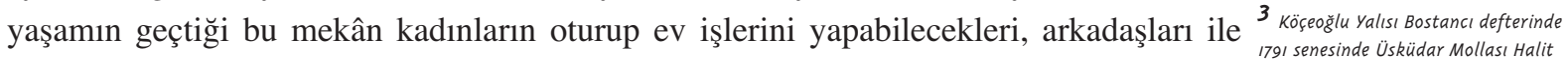
sohbet edebilecekleri, minderlerle döşenmiş, halı kaplı bir yerdir. Planı oluşturan eleman- Efendi'ye ait görülmektedir. 


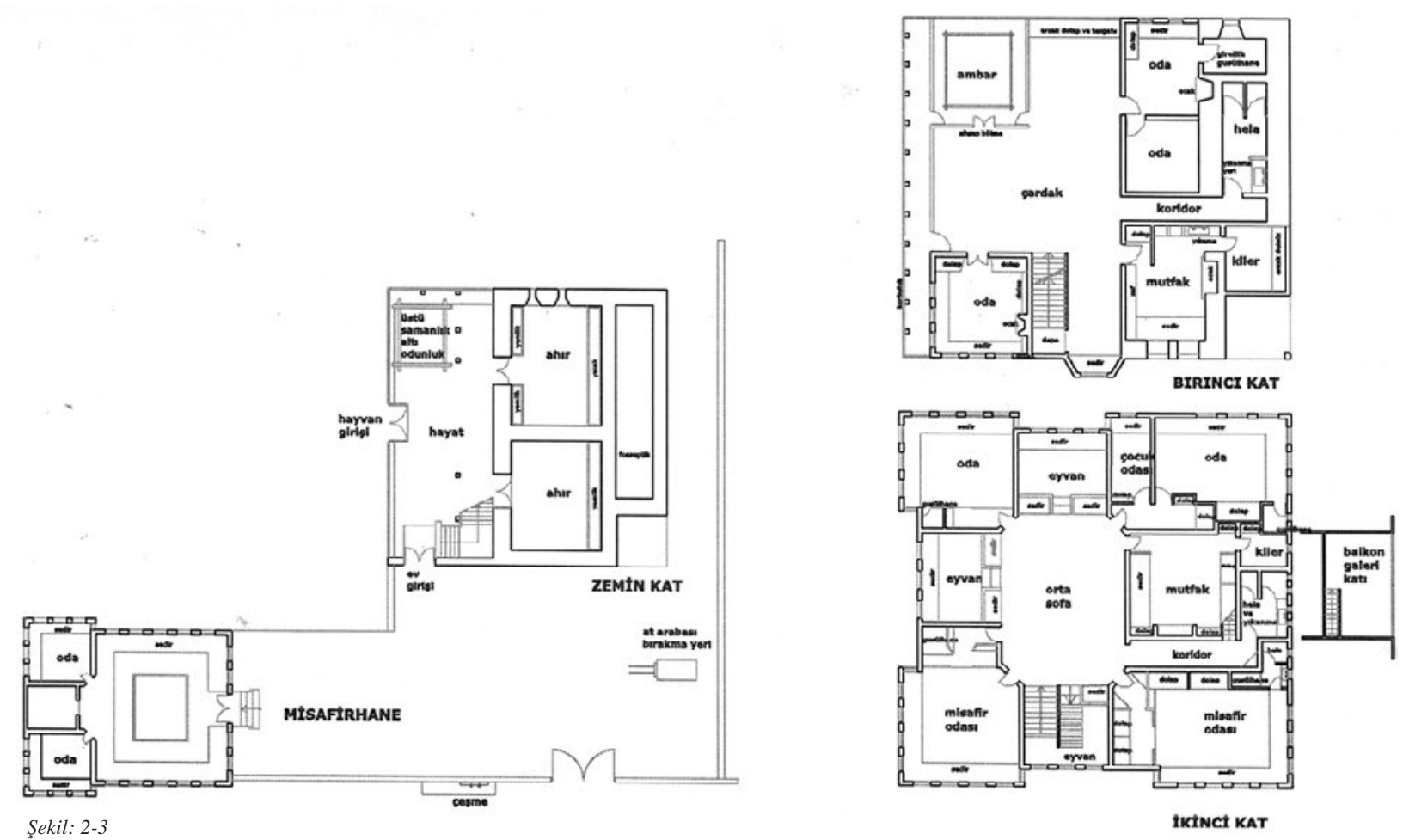

Şekil: 2-3

Rauf Beyler Talat Hidayetoğlu Evi. Dört odalı ve dört eyvanlıdır. Plandaki bahçe köşkü Bebek'teki Köceoğlu Yalısı'nın selamlık kısmina benzemektedir (Yanmıs olan bu yapı bugün yoktur). lar (oda, eyvan, sofa) değişik arsa koşullarında, değişiklik düzenler içinde kullanılmıştır. Eyvanlardaki seki ile sofa arasındaki direklik Kuban'ın $(1995,130)$ belirttiği gibi bazı zengin Safranbolu evlerinde de vardır:

Direkliğin ortadaki yanlardan daha geniş üç açıklığı vardır. Yanlardaki açıklıkların kenarlarında korkuluk yapılmıştır. Böylece ayırt edici bir öğenin kullanımı, yalnızca getirdiği nitelik ve bezemesi açısından değil, mekânın işlevsel olarak farklı iki bölüme ayrılmasını güçlendiren bir etki yaratması nedeniyle de mekân etkisini zenginleştirir. Seki üstünün seki altından bir revakla değil yalnızca parmaklıkla ayrıldı ̆̆ı örneklerde bulunmaktadır.

Sofalar odaların adedine ve evdeki konumlarına göre farklı şekillerde olabilir. Genellikle üst katlarda oda adedinin bir ya da ikiyi geçmediği evlerde diş sofa bulunur. Diş sofalar dikdörtgen şeklinde olabileceği gibi 'L' şeklinde de olabilir. Ara kat sofalarından hayata bakan galerili olanları da vardır.

Orta sofalı evlerde de odalar sofanın iki kenarında dizilir. Bunların genellikle iki ucunda eyvanlar bulunur. Eyvan sayısı dörde kadar çıkabilir. Bu sofaların uçlarında sekili eyvanlar yer alabilir. Bazen eyvanın içine merdiven ve helâ yerleştirilir. Orta sofalı evlerde plan simetriktir ve genellikle sofanın etrafında dört oda yer alır. Bu odalara sofadan üst katlarda pahlı kapılarla girilir. Bu şekilde sofa sekizgen bir geometriye sahip olur. Sofanın dört tarafında eyvanlar olabileceği gibi bu eyvanların bazıları oda, bazıları ise helâ ve merdiven için kullanılır. İç sofalı örneklerde bazen bir, bazen daha çok basamakla çıkılan eyvan içindeki sekili oturma mekânı oluşturulmuştur. Bu mekânda pencere önünde sedir yer alabilir. Sofalarda yer alan eyvanlar çıkma yapabilir. Buraları daha çok günlük oturma mekânlarıdır. Bu eyvanların çıkma yapanları yazlık olarak adlandırılır; tavanları odalara ve sofaya göre daha alçaktır.

Odaların ve özellikle iç sofaların tavanlarına özenle çıtalar kullanılarak desen verilmiştir. Başodalarda ve üst sofalarda genellikle göbekli ve köşelerinde dörtte bir göbekli 
süslemeler tipik Safranbolu özelliğidir. Üst sofalar genel olarak ters bir tekne gibi çatı içine doğru yükseltilmiştir. Göbek ortasında da bu sofalarda avize yer alır. Bazı zengin konaklarda eyvanlarda tavan süslemeleri yapılmıştır. Nadiren bazı zengin evlerde odalarda ve sofada tavanla sergen arasında boyalı süslemeler vardır. Duvarları desenli boyanmış evlere de rastlanmaktadır. Bunlar genellikle yurt dışı ile ticaret ilişkisi olan ya da İstanbul ile temasta bulunmuş ailelerde görülen örneklerdir.

Zemin katlar geçmişte ahır, odunluk, kömürlük gibi işlevlere ayrılmıştır. Evlerin zemin katında bir taşlık ya da hayat yer alır. Eğer zemin taş kaplıysa taşlık, toprak olarak bırakılmışsa hayat adını alır. Kentin eğimli olması nedeniyle taşlık bazı hallerde daha üst kotlarda da bulunabilirs. Safranbolu'da hayat ya da taşlık büyük yontulmuş düşey tahtalardan yapılmış kafeslerle (gliste) kapatılmış giriş katıdır. Glistelerin önünde bahna üzerinde odunlar dizilerek kurutulur. Birinci kat sofasına çardak denmektedir (Kuban 1995, 138). Hayat'ın sokağa ve komşulara bakan cepheleri kafeslerle (muşabak) kapatılmıştır. Sokak tarafına cumbalı kafesler bakmaktadır. Bu katta kazan ocağı ve büyük mutfak yer alabilir. Evin iç çeşmesi de buradadır.

\section{Mekân Tipolojisi}

Evlerin genel sınıflamasını yapabilmek için tipoloji yapmayı hedefledik. Bu şekilde binaların hiyerarşik olarak fiziksel nitelikleri ortaya konulabilecektir. Bu arada binaların biçimsel dili belirlenebilecek ve morfolojisine ulaşılacaktır. Burada yapılmaya çalışılan oda, sofa ve eyvanlardan oluşan üst kat planlarına dayanarak genel morfolojik yapıyı ortaya koymaktır. Bu nedenle merdiven ve helâlar sadece doluluk olarak gösterilmiş, balkonlar gibi bazı elemanlara yer verilmemiştir. Merdivenlerin ve diğer elemanların tipolojileri yapılabilse de burada sadece genel tipoloji (oda, sofa, eyvan, merdiven) üzerinde durulacaktır. Binaların mekân ve kat sayıları genellikle kullanıcı ihtiyaçlarından kaynaklanmaktadır. Bağlardaki yazlık bir evde ticari ilişkiler olmadığı için minimum temel ihtiyaçlara göre yapı şekillendirilirken, çarşıdaki kışlık evler aynı zamanda misafir ağırlama ve iş görüşmeleri yapılan mekânlara sahiptir. Bu nedenle yalnız üst katlara göre yapılan tipoloji çalışması ailenin zenginliğini ya da ihtiyaç hiyerarşisini yansıtmamaktadır. Bu nedenle bütün evdeki oda sayıları da önem taşımaktadır.

Safranbolu'ya ait elimizde bulunan 47 rölöveden bir ev planları tipolojisi çıkarılmaya çalışılmıştır. Ancak bu plan tiplerinin bazıları, öğrencilerin tez çalışmasından sonra tarafımızdan eklenmiştir. Safranbolu evlerinin çoğunluğunda arazi durumuna da bağlı olarak genellikle iki ya da üç esas kat bulunmaktadır. Safranbolu eğimli bir arazide kurulmuş olduğu için evlerin kat sayısı ve odaların konumları arazinin eğimine ve eve yoldan girişe göre belirlenmektedir. Ayrıca ailenin prestij ve yeni evlenen çocuklara yer bulmak için bazı hallerde kat adedini artırdığı düşünülmektedir.

\section{Zemin ve Ara Katlar}

Evlerin zemin üzerinde ara katları ve üst katları vardır. Çoğunlukla ara kat planı üst kat planını tekrar eder ve bazen değişiklikler gösterir. Zemin katta da bazen üst kat planı tekrar edilir. Sadece bir oda kaldırılarak, girişte sofa ile birlikte büyükçe bir taşlık elde edilir. Diğerlerinde ise zemin kat ahır veya ahır-taşlık şeklinde bölünür. Bütün Türk evlerinde olduğu gibi, ana plan şeması üst kattadır. Planı oluşturan başlıca elemanlardan biri odadır. Plan tipinin meydana gelmesinde en çok etkili olan ise oda sayısıdır. Burada $\mathbf{4}_{\text {Bu tür süslemeleri evin }}$ sahiplerinin prestij işin yaptirdikları düşünülmektedir. yaptı̆̆ımız bir araștirmada evleri dis görünüşleri ile değil eğer içine girdilerse is görünüşleri ile tanıdıklarını çeure halkı belirtmiştir.

$5_{\text {Safranbolu evlerinin plan }}$ tipolojisi çalışması 1978-79 akademik yilında Nigan Bayazıt'ın yürütücülüğü altinda Perihan Bulduk tarafindan yapilan "Safranbolu Konutlarinin Plan Tipleri" (1979), ITÜ MMLS Eğitim Programı kapsamindaki yüksek lisans tezine dayanmaktadir. 
$\sigma_{\text {Plan tipolojisindeki }}$ semalarda kullanilan temel başliklar üst kat planları esas alınarak oluşturulmuştur. geliştirilen çalışmada oda sayısı, oda biçimi ve odanın yönünün önem taşıdığı görülmüştür. Yapılan tipolojide üst kattaki oda sayısına göre aşağıdaki semboller kullanılmıştır6.

Oda sayıs1 $(\mathrm{O} 1, \mathrm{O} 2, \mathrm{O} 3, \mathrm{O} 4)$,

Oda şekli (O11, O12, O21, O22, O23, O31, O32, O33, O34, O34, O41, O42, O43, O44, O45). Zeminde yer alan ahır, hayat ya da taşlık mekânları genellikle evin sahip olduğu hayvanları barındırmak ve büyük ocak gerektiren ev işlerini yapmak için kullanılır.

\section{$\ddot{U}$ st Kat}

Üst katlar oda sayılarının belirlenmesindeki en önemli şemaları verir. Safranbolu evlerinde dört odalı ve üç odalı planlar çoğunluğu oluşturmakta, iki odalı ve çok az sayıda da bir odalı plana rastlanmaktadır. Odaların hepsi dik açılı değildir. Bazılarında içteki bir köşe pahlıdır ve burada genellikle kapı yer alır. Kapı yer almayan pahlı köşeli odalar da vardır. Bunlar sofanın biçimini sekizgen yapmak için uygulanırlar. Bu tür pahlı girişler genellikle daha alçak tavanlıdır ve üstlerinde musandra boşluğu ya da dolaplar yer alır. Arsaların genellikle dik açılı olmamasından dolayı odalarda çıkma yapılır. Planda oda veya odalar çıkma yaparlar, böylece diğer yönlere de bakış sağlandığı gibi, odanın biçimi kareye ya da dikdörtgene yakın bir geometriye getirilir. Binalar çoğunlukla dört ya da üç yöne bakar. İki veya tek yöne bakan planlara da rastlanmaktadır. Odaların baktıkları yönler ne olursa olsun bir dış duvarda genellikle üç pencere yer alır.

\section{Eyvan}

Planı oluşturan diğer bir eleman da eyvanlardır. Eyvan odaların arasına giren sofanın uzantısı olan bir mekândır. Plan tipinin meydana gelmesinde eyvanların etkisi vardır. Genellikle sofanın etrafına dizilen odalar ve onların arasında yer alan eyvanların oda sayılarına bağlı olarak adetleri değişmektedir. Bu çalışmada eyvan sayılarına dayalı bir tipleştirmeye gidilmiştir. Eyvan sayısı evlerde birden dörde kadar çıkmakta, bazılarındaysa hiç eyvana rastlanmamaktadır. Yalnız E harfi ile eyvansız evler ifade edilirken diğerleri sırayla numaralanarak açıklanmaktadır.

Eyvan sayısı (E, E1, E2, E3, E4) birden dörde kadar değişir.

Eyvanlar odalar arasındaki boşluğu dolduran bir modül olarak kabul edilebilir. Bu şekilde evlerde haçvari bir şema ortaya çıkmaktadır. Eyvanlar dışa çıkmalarına ya da içe doğru girinti yapmalarına göre ve başka işlevlere ayrılıp, dolu ya da boş olmalarına göre gruplanabilmektedir. Zemin ya da ara kata göre odalar çıkma yapıyorsa, eyvanlar birçok halde çıkmasız olup, alt katlar hizasında kalmaktadır. Eğer odalar çıkma yapmıyorsa, bu defa eyvanların içeride oturanların görüş açısını genişletmek için çıkma yaptıkları saptanmıştır. Grafik çizimlerdeki ME sembolü eyvanlardaki merdiven için kullanılmıştır.

Eyvanın şekli (planda dışa doğru çıkma, içe doğru girme yapması),

Eyvanının doluluğu ya da boşluğu.

Eyvan çıkmaları düz olduğu gibi, bazen köşeleri kırılarak pahlanmıştır. Eyvanın pahlandırıldığı durumlarda pencereler de eyvanın bu pahlı kısımlarında ve ortada yer alarak sokak ya da bahçe görüşünü genişletirler. Eyvanların farklı şekillerde biçimlendirildiği görülmektedir. Eyvan sofanın uzantısı olarak devam edebilir. Bu durumda döşemede herhangi bir fark yapılmaz. Bazı hallerde sofanın uzantısı olarak devam ederek, direklerle sofadan ayrılabilir. Bazen direklerin arasına camlı bölme ve kapı konabilir. Direklerle ayrılanlarda bir ya da birkaç basamaklık bir kot farkı (seki) yapılabilir. Eyvan 
bir oda gibi kapı ile sofadan ayrılabilir. Eyvanların tavanı genellikle sofadan daha alçak tutulur. Eyvanın dolu olması durumunda merdiven, abdestlik, helâ ya da kiler hacimleri ile kapatılmıştır. Bu mekanlar modül gereği yerleştirilmelerine rağmen, artık eyvan niteliği taşımazlar. Evlerin bazılarında bir eyvanı dolu olanlar, iki eyvanı dolu olanlar ve üç eyvanı dolu olanlar bulunur.

\section{Sofa (Çardak)}

Ev planlarının diğer bir elemanı da sofadır. Safranbolulular tarafından sofaya çardak denmektedir. Safranbolululara göre odalar sofaya açılır, sofa bir veya iki tarafı kapalı olduğu gibi, ortadadır ve dört tarafı da kapalı olabilir. Sofalı ev planları dış sofalı, iç sofalı ve orta sofalı plan tipleri olarak ayrılabilir.

\section{Odalar}

Türk evinde en önemli birim odadır. Her oda evli bir çifti barındıracak özellikte tasarlanmıştır. Her odada oturulabilir, yatılabilir, yıkanılabilir, yemek yenilebilir ve hatta yemek pişirilebilir. Odaların büyük bir çoğunluğu aynı özelliklere sahiptir. Bu özellikler geleneksel ataerkil aile yapısıyla ve yaşama biçimiyle ilgilidir. Aile yapısı ve ekonomik düzen çok uzun yıllar değişmediği için oda tasarımı da aynı kalmıştır. Odaların yukarıda sayılan değişik eylemlere cevap verebilmesi için esnek bir planlamaya gidilmiştir. Safranbolu evlerinde odalar birbirinden bağımsız birimler olarak sıralanırlar. Yalnız bir bazen iki kapıyla odalar arasındaki sofayla bağlanırlar. Osmanlı evlerinde odalardan başka mekânlara geçit verilmez. Genellikle odalar birbirine bitişik yapılmazlar. Aralarına ya eyvan ya da başka mekânlar yerleştirilir. Sıra odalara da Safranbolu'da rastlanmaz.

\section{Taşlık, Hayat, Kiler ve Ahır}

Safranbolu evlerinin sokak katı dışa tamamıyla kapalı taş duvarlarla çevrilidir. Binaya zemin kattan girişler yer taş kaplıysa taşlıktan, toprak olarak bırakılmışsa hayattan yapılır. Bu katta ailenin büyük ve küçük baş hayvanları için ahır, samanlık gibi mekânlar bulunur. Ayrıca bu katta evin hanımlarının kullandığı kazan ocağı ve erzakın saklandığı ambarları olan kilerler bulunur. Ailenin büyüklügüüne ve zenginliğine göre bu mekânlar değişiklik gösterir.

\section{Plan tipleri}

$\mathrm{Bu}$ açıklamalara göre planlar sıralanarak, aşağıdaki tablolar ve evlerin grafik şemaları oluşturulmuştur. Böylece yalnız üst katlara bağlı kalınmayarak evdeki oda sayılarının önemi de vurgulanmaktadır. Evlerdeki oda sayıları ailenin genişliğini ve bir ölçüde de zenginliğini, iş ilişkilerini, üretim kapasitesini yansıtmaktadır.

\section{Tek Odalı Evler}

Üst katında tek odalı tipler çok az sayıdadır ve bunlar zorunlu olarak iki katlı ve de dış sofalıdır. Zeminde taş duvarlar ve hayat ile bir hacim daha bulunur. Genellikle yazlık evlerde tek odalı tipe rastlanmaktadır. Bu evler küçük bir ailenin fizyolojik ve güvenlik ihtiyaçlarını minimum düzeyde karşılayacak şekilde yapılmıştır. Komşularla ve arkadaşlarla sınırlı düzeyde bir ilişki kurulabilmekte olduğu görülmektedir. Tek odalı evlerde üst katta sofa 'L' şeklindedir (Şekil 4).

$8 \mid$ sayı 17, 2014 


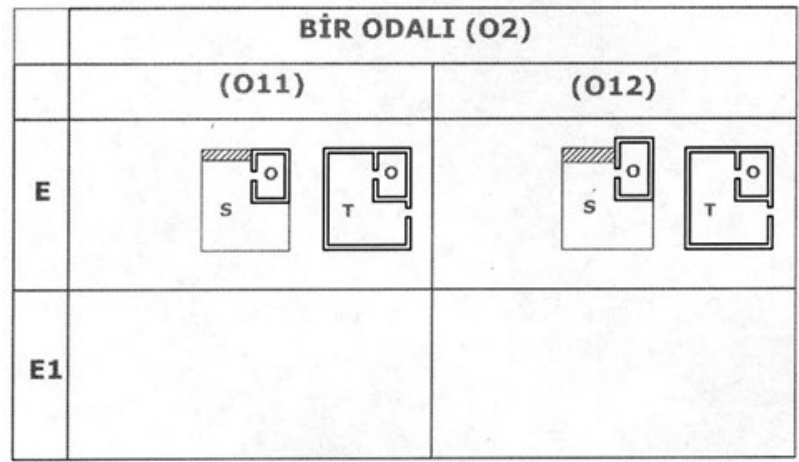

Şekil: 4

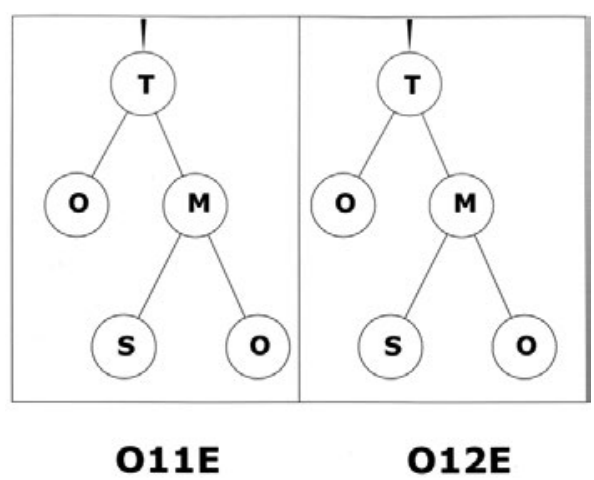

O12E

\section{Iki Odalı Evler}

Üst katı iki odalı evlerden eyvanı olmayanların dış sofası bulunmaktadır ve odalar sofanın bir kenarında dizilmiştir. Tek eyvanlı iki odalı evlerde dış sofa ve orta sofa olduğu görülmektedir. Bu tiplerde yalnız bir tanesi iki katlı, diğerleri üç katlı olarak yapılmıştır. İki katlı dış sofalı O21E1 tipinde kullanılabilir yalnız iki oda olduğu görülmektedir. Bu ev de küçük bir ailenin fizyolojik ve güvenlik ihtiyaçlarını minimum düzede karşılayacak şekilde yapılmıştır. Eyvan sofanın bir tarafında yer almaktadır. Sofada eyvanın bulunması bazı sosyal, arkadaşlık ilişkilerine işaret etmektedir. Zemin katta genellikle hayat, bazen kömürlük yer almaktadır. İki odalı eyvanı dolu olan evlerde genellikle merdiven ve helâ bu bölümde yer almaktadır. Üç katlı olan evlerde oda sayıları dört ve beş olarak görülmektedir. Bu evler büyük aileler için düşünülmesi nedeniyle, zemin katları üretime ve hayvan barınağına elverişli olarak tasarlanmıştır. Bu evler, temel ihtiyaçlar dışında ailelerin zirai ve ticari ihtiyaçlarını karşılayacak nitelik taşımaktadır.

İki odalı dış sofalı evlerin bazılarında hiç eyvan bulunmazken, dış ve orta sofalı tiplerin bazılarında eyvanlar çıkıntılı olarak görülmektedir. Bu tiplerde sofa genellikle bir köşede

şekil: 4 Bir Odalı ve Eyvansiz L Dis Sofali Tipler ve Onlarin Grafik Anlatımları.

şekil: 5

Iki Odalı Eyvansiz, Bir Eyvanlı ve Eyvanı Dolu, Dis ve iş Sofalı Tipler. yer almaktadır. Yalnız bir eyvansız ev planında sofa boydan boya devam etmektedir.

İki odalı olup üç katlı olan evler genellikle çarşıda yer alırlar ve ev sahiplerinin toplumsal ve iş ilişkilerini sürdürdükleri yapılardır. Gerek kadınların gerekse erkeklerin arkadaşlık ve iş ilişkileri için yeterli mekânları vardır. Üst katta bir baş oda ve ara katta özellikle O23E1 tipinde selamlık odası olabilecek bir oda bulunmaktadır. Diğer tip planlarda eyvanlar aynı yüzde, içerde ya da çıkıntılı olarak yapılmıştır (Şekil 5-6-7).

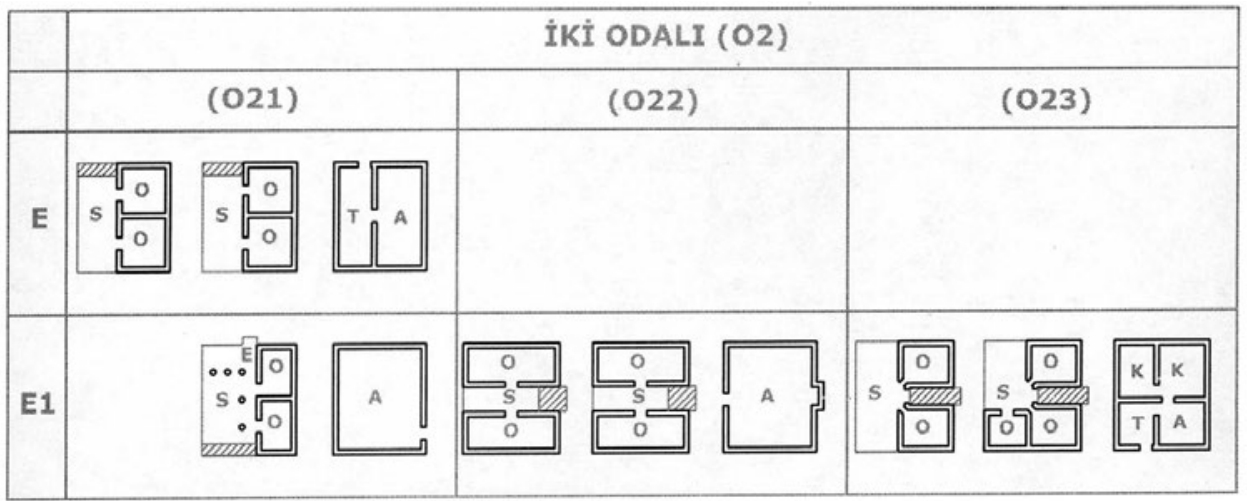




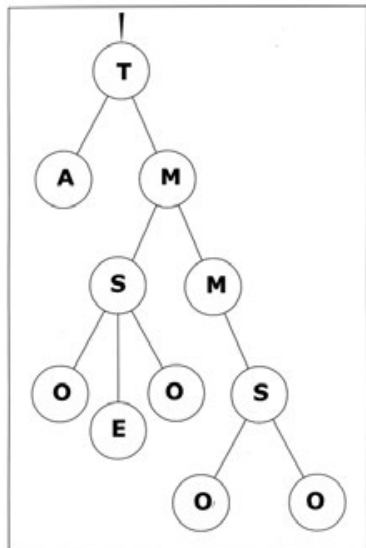

Şekil: 6
O21E

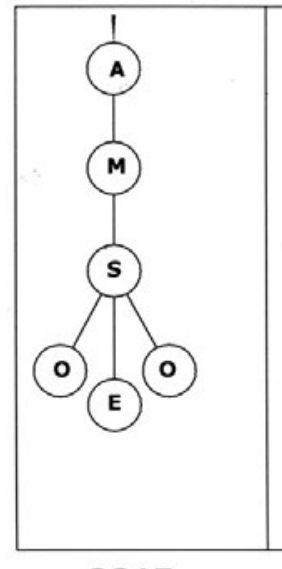

O21E1

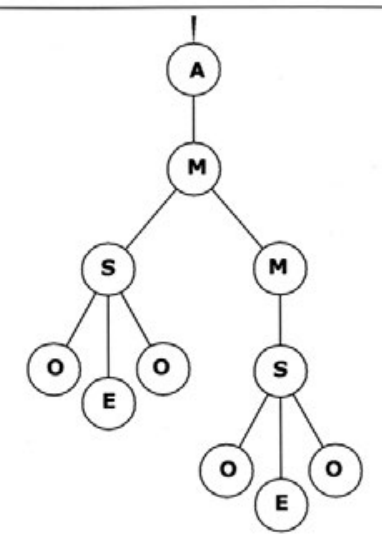

O22E1

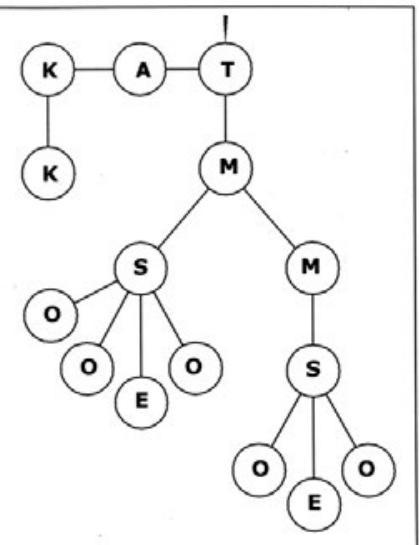

O23E1 Şekil: 7

\section{$\ddot{U} c$ Odalı Evler}

Bu evlerin hepsi üç katlı tipik Safranbolu evidir. Eyvansız dış sofalı ve üç odalı evlerde sofanın bir kenarında merdiven ve helâya yer ayrıldığı görülmektedir. Üç odalıların tek eyvanlı olanlarında, eyvan mutlaka merdiven ve helâ için kullanılmaktadır. Üç odalı evlerin iki eyvanı dolu olanlarının yine merdiven ve helâ için kullanıldığı görülmektedir. Üç eyvanı olan bu tip planlarda eyvanın biri boş kalmakta ve seki ile yükseltilerek günlük oturma için tahsis edilmektedir. Dört odalı evler arasında yalnız bir tanesi dış sofalı olarak tasarlanmıştır. Bu tiplerde iç ve orta sofa etrafında odalara girişler genellikle pahlanmış orta sofadan yapılmaktadır. Dört odalı evlerin bazıları iki, bazıları üç

Şekil: 6

Eyvansiz Evin Grafik Anlatımı.

Şekil: 7

iki Odalı ve Bir Eyvanlı Tiplerin Grafik Anlatımı. sekil: 8

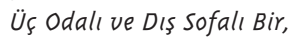
iki ve Ü̧ Eyvanlı Tiplerin Grafik Anlatımı.

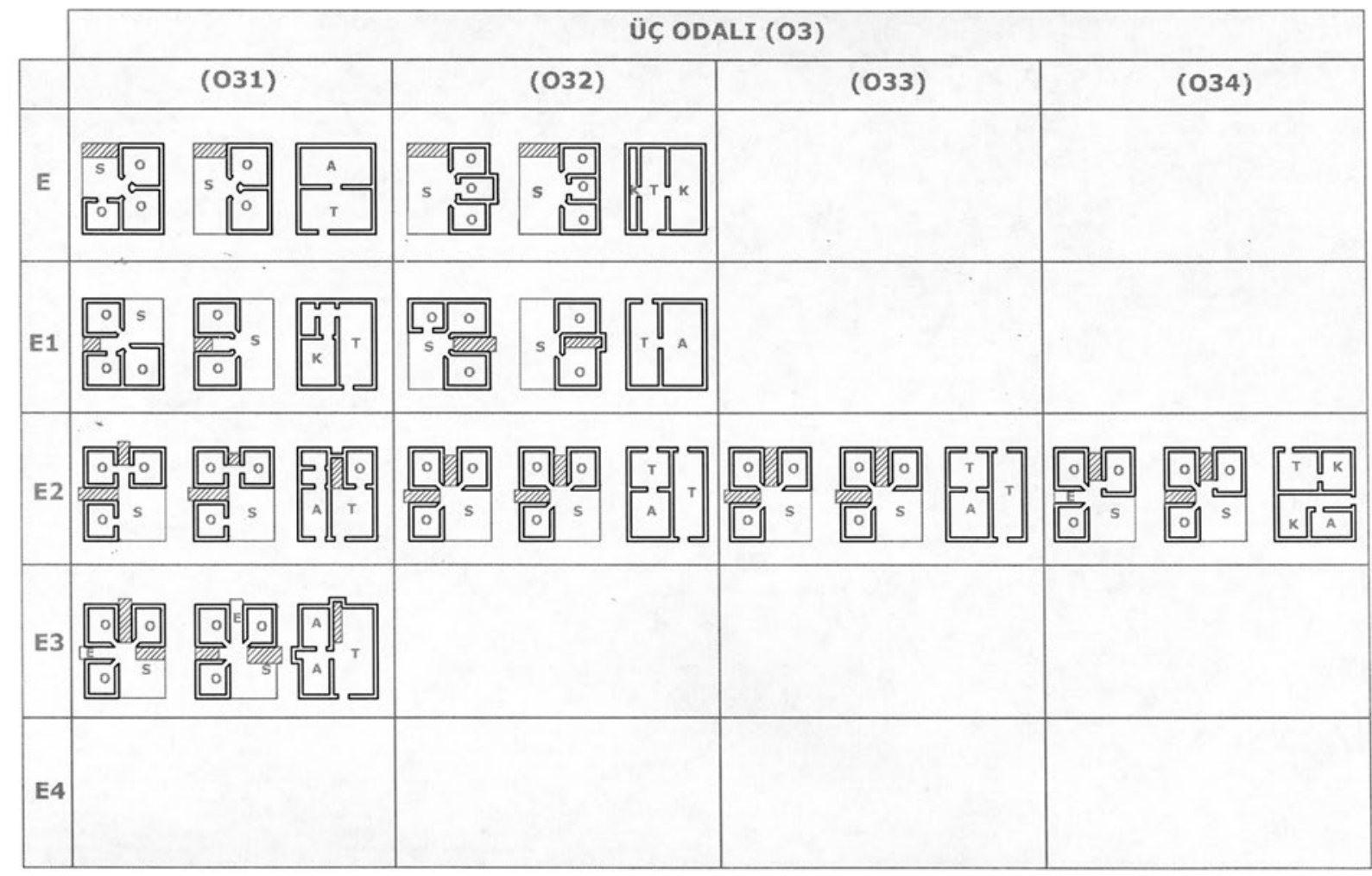




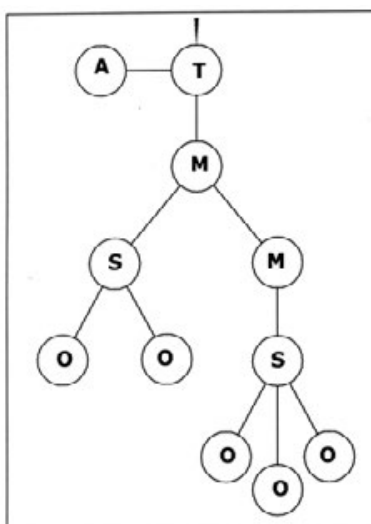

Şekil 9
O31E

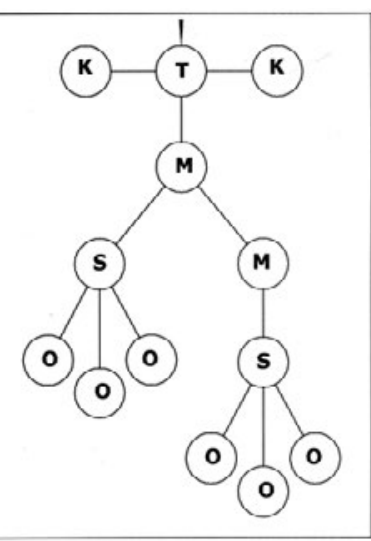

O32E

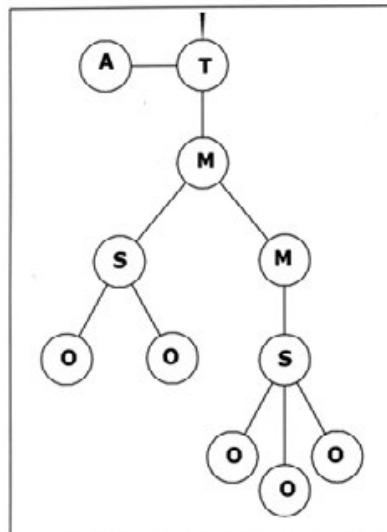

O31E

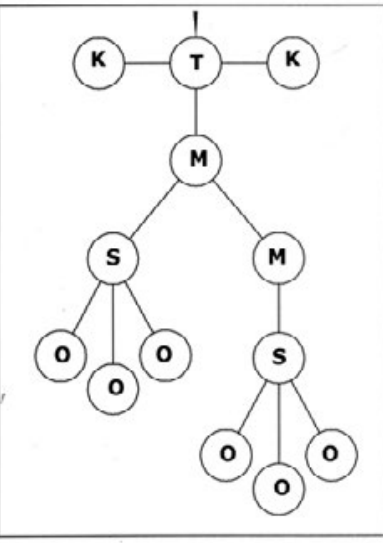

O32E
Şekil: 9

Ü̧ Odalı ve Dıs Sofalı Eyvansiz ve Bir Eyvanlı Tiplerin Grafik Anlatımı. bazılarında zemin katta da odalar yer almaktadır. Safranbolu'da Türklerin evlerinde zemin katta genellikle dükkân bulunmaz. Genellikle Rum evlerinde bir dükkân vardır. Ancak bu evlerin birçoğunda ara katta ya da zemin katta erkek misafirlerin kabul edildiği selamlık kısımları vardır. Bu mekânlar özenle evin diğer kısımlarından ayrılmıştır. Selamlık kısımları erkeklerin ticari iş ilişkilerini sürdürdükleri sosyal mekânlardır. Bu evlerde üst katlarda başoda bulunur ki, bu mekân evin en itibarlı yeridir. Bu mekânın ve bu mekânın bulunduğu sofanın tavanı özenle süslenmiştir. Bazı evlerde başoda duvarları farklı bir şekilde resimlerle ve desenlerle süslenmiş prestij mekanlarıdır (Şekil 8-9-10-11).

\section{Dört Odalı Evler}

Genellikle bütün evlerde zeminde taşlık bulunmaktadır. Dört odalı ve dış sofalı evlerde eyvan bulunmamaktadır. Buna karşılık diğer dört odalı evlerde üç ya da dört eyvan bulunmaktadır. Eyvanların bazen biri bazen ikisi evin büyüklüğüne göre doludur ve buralara hela, kiler ya da merdiven yerleştirilmiştir. Orta ve iç sofalı tiplerde kapılar pahlı olarak sofaya açılmaktadır. Boş kalan eyvanlar seki ile yükseltilerek ve bazen direklikle sofadan ayrı bir mekân haline getirilmiştir. Bu eyvanlarda genellikle pencere önünde sedir de bulunmaktadır.

Sonuç olarak Safranbolu evleri plan şemalarının morfolojik yapısı açısından diğer Osmanlı evlerinden farklı değildir. Evler genellikle ayrık düzende yapılmıştır ve iki, üç, dört yöne bakmaktadır. Evlerin içe kapalı bahçeleri vardır. Genel Osmanlı ev tipleri içinde görülen hayatlı ev tipine Safranbolu'da da rastlanmaktadır. Sofa evlerde bütün yaşamın geçtiğ i ve işlevlerin toplandığı bir mekândır. Her evde sofa vardır. Odalar sofanın bir, iki ya da dört tarafında yer alır. Üst katlarda oda sayısı dördü geçmez. Eyvan sayısı ise birle dört arasında değişir. Bu evlerin çoğunluğu iki katlıdır. Kat sayıları az olmasına karşılık oda sayıları dörtle yedi arasında değişmektedir. Zemin katında oda olanlar haremselamlık olarak iki kısımlı evler olup, bunlar sosyal ilişkilerin varlığını işaret etmektedir. Zemin katında ahırı olmayan evlerin ahırları dışarıda ayrı bir mekânda yer alır. Bütün evlerde bir taşlık mutlaka vardır. Evlerdeki oda sayıları ataerkil ailenin genişliğini açıklamaktadır. Bu evlerde üst katta odalardan biri süslü tavanlı başodadır ve sofa da genellikle sekizgen olup, ters tekne gibi süslü bir tavanı vardır (Şekil 12-13-14-15) (Resim 6-7-8-9). 


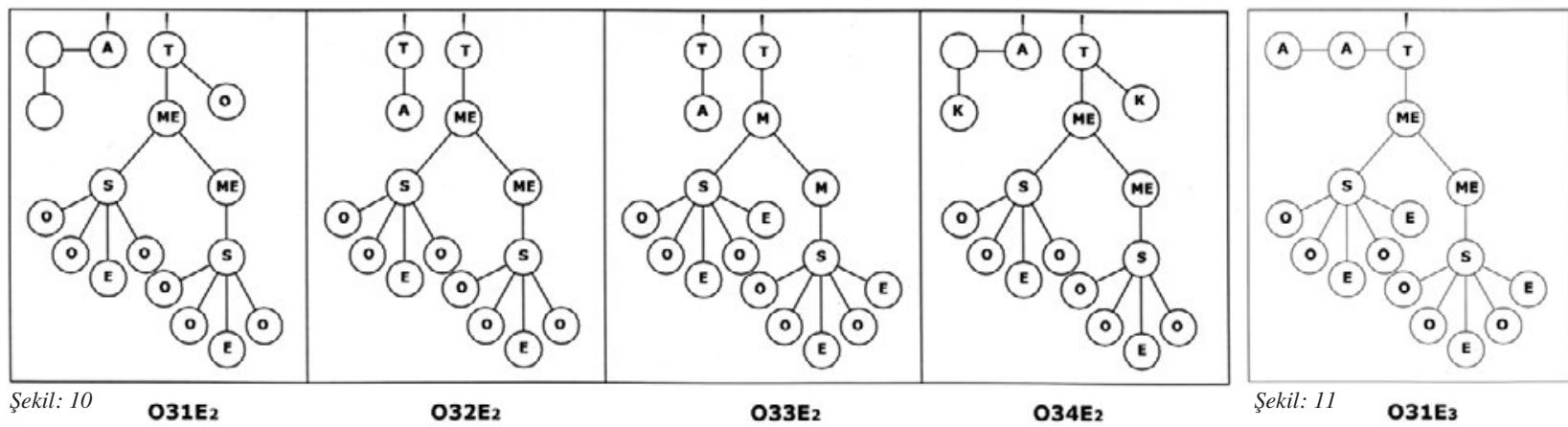

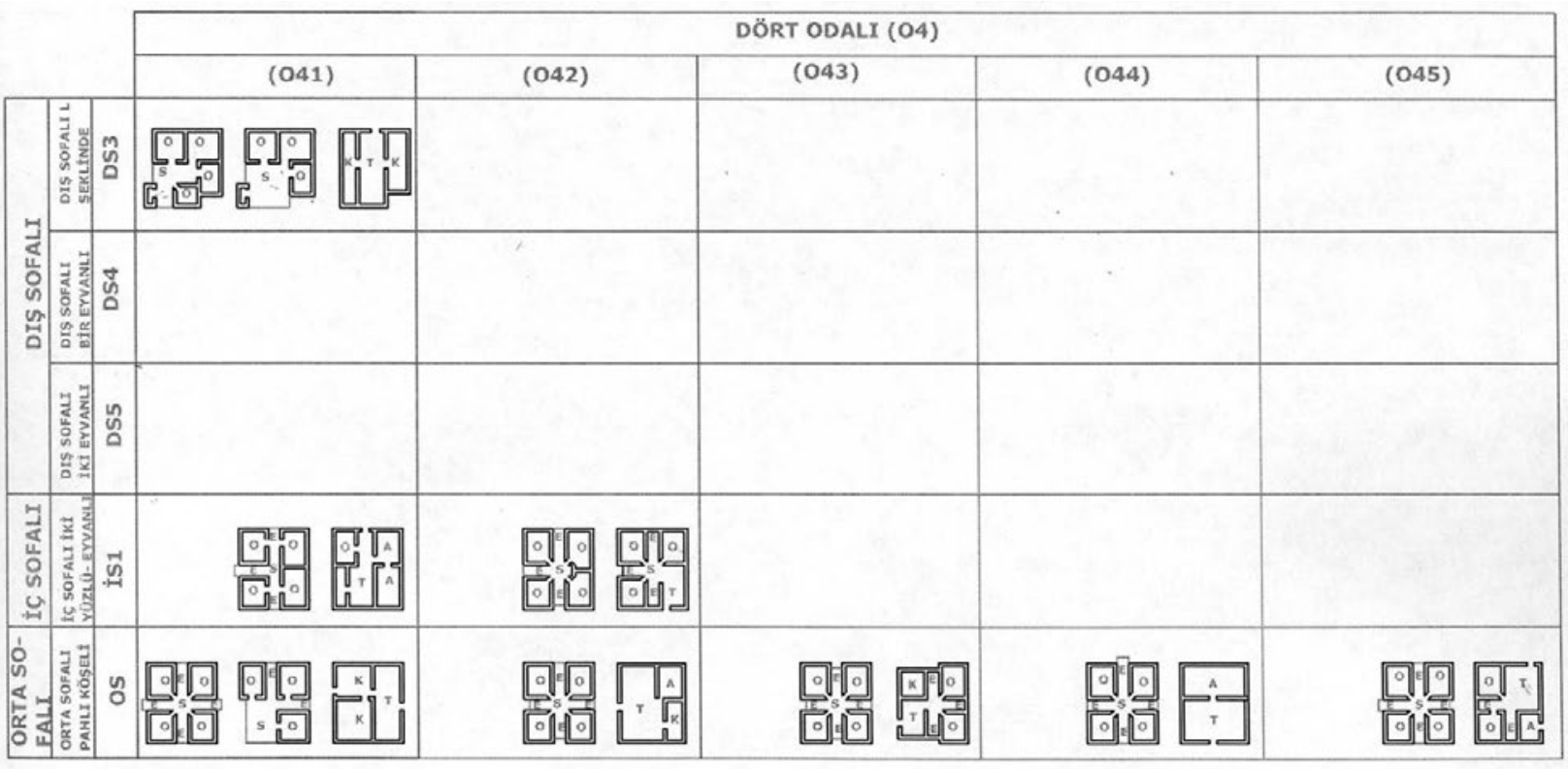

Şekil: 12

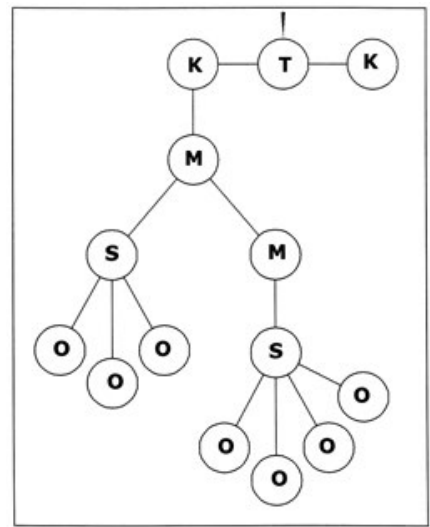

Şekil: 13
O41E

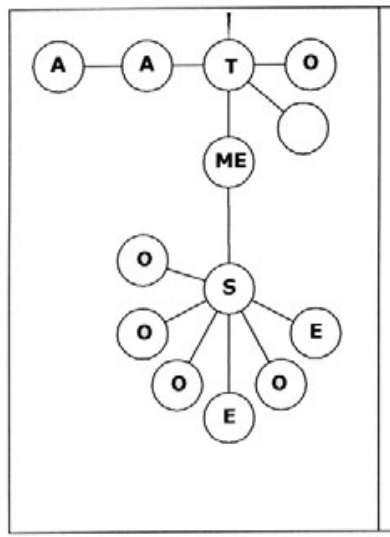

O41E3

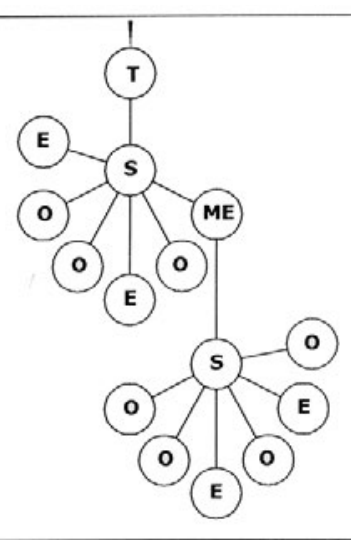

O42E3
Şekil: 10

Ü̧̧ Odalı ve Dış Sofalı Iki Eyvanlı Tiplerin Grafik Anlatımı.

şekil: II

Ü̧̧ Odalı ve Dıs Sofalı Ü̧ Eyvanlı

Tiplerin Grafik Anlatımı.

Şekil: 12

Dört Odalı Dıs, Orta ve iç Sofalı Eyvan Sayısına göre Plan Tiplerinin Grafik Anlatımı.

Şekil: 13.

Dört Odalı Dıs Sofalı Eyvansız Evin Grafik Anlatımı.

Şekil: 14.

Dört Odalı Orta ve iç Sofalı Ü̧ Eyvanlı Eulerin Grafik Anlatımı. 


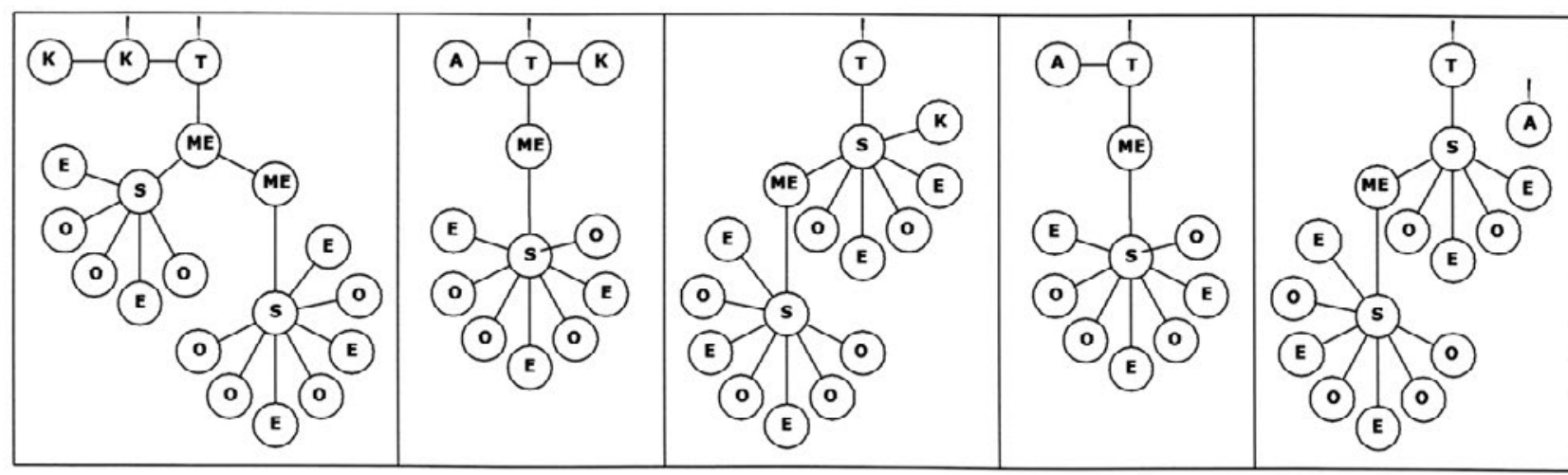

Şekil: 15 O41E4

$042 E_{4}$

O43E 4

O44E 4

O45E $_{4}$

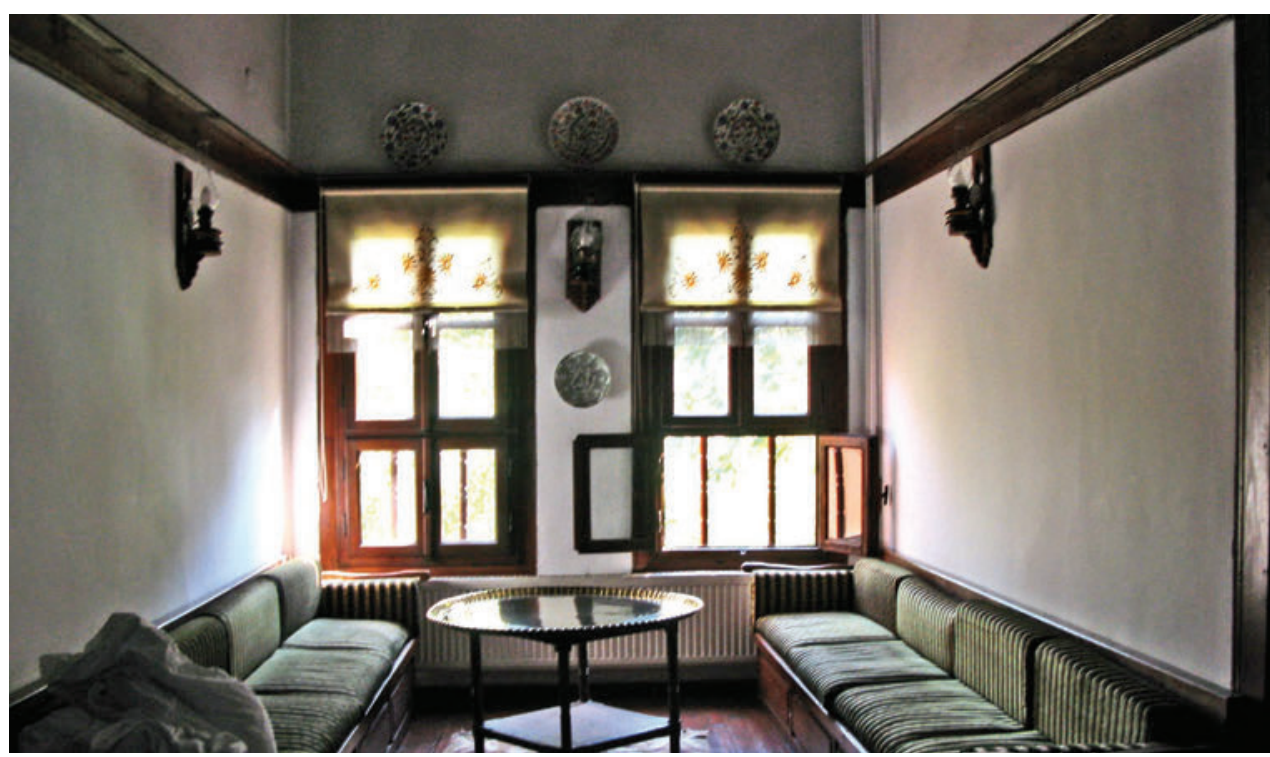

Şekil: 15

Dört Odalı iş Sofalı, Dört Eyvanlı Evlerin

Grafik Anlatımı. Resim: 6 Gökçüoğlu Konağı'nda fikmalı Bir Oda.

Resim: 7 Asmazlar Havuzlu Konağı'nda Üst Kat Eyvanı (Bugün otel olarak kullanilmaktadir).

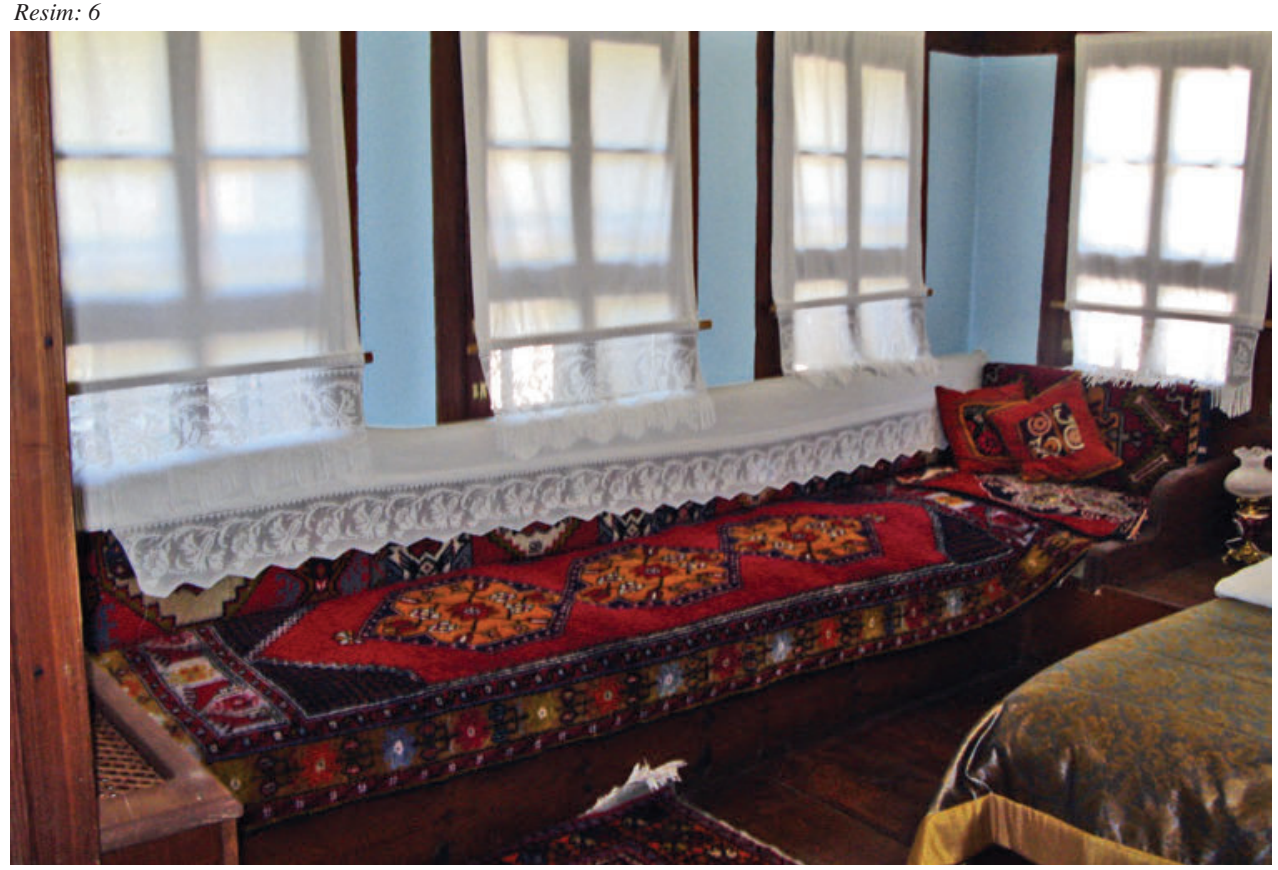




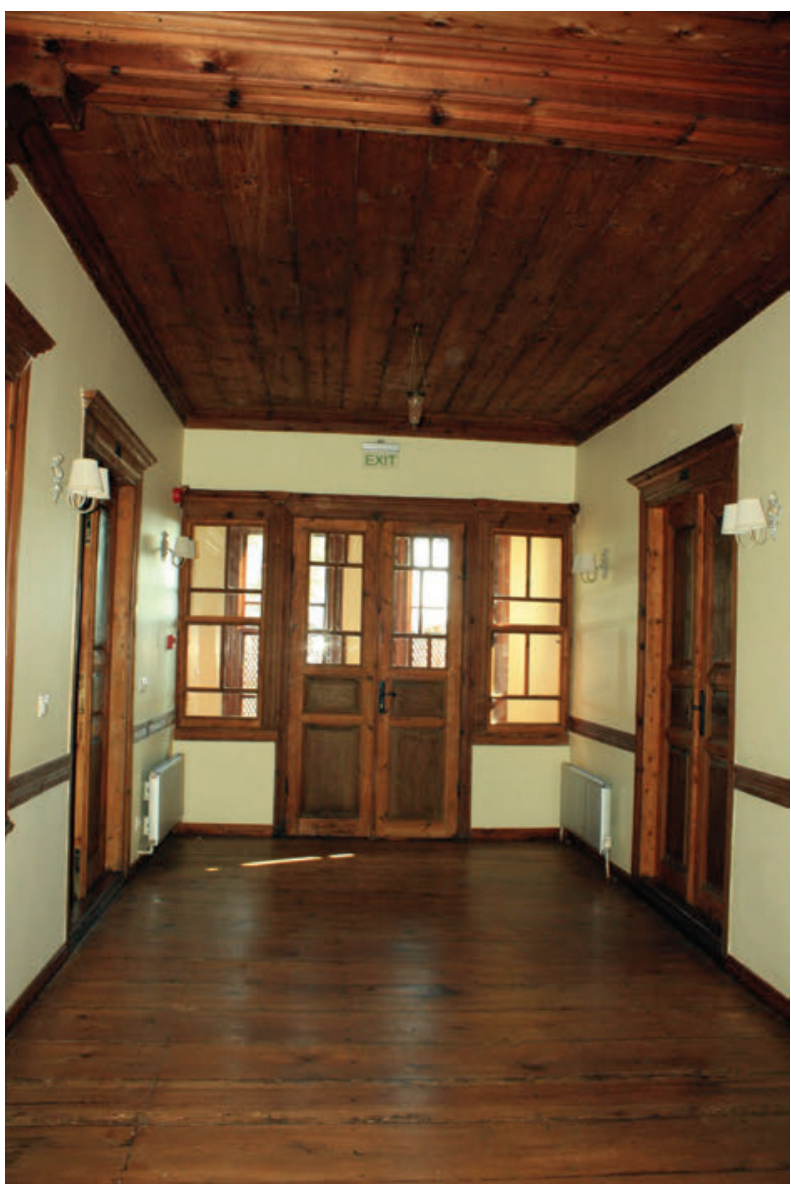

Resim: 8

\section{Sonuçlar}

Safranbolu, 100-150 yıllık evleri olan ve 1994 yılında UNESCO tarafından dünya mirası kabul edilen bir Osmanlı kenti olarak korunmaktadır. Gerçek özellikleri ve görünümü ile korunmuş bir kenttir. Çevresinde geniş ormanlık alanların bulunması kentin bozulmadan kalmış olması üzerinde önemli bir etkendir.

Binaları okumanın bir türü olarak bu tipoloji çalışması gerçekleştirilmiştir. Kentteki yapıların elimizde 47 adedinin planlarının bulunması ve her büyüklükte ev örneğine sahip olmamız, bu tipoloji çalışmasını yapmamızı sağlamıştır. Yalnız odaların kat planlarında şematik anlatımlarına birçok yayında rastlanmaktadır. Ancak Safranbolu evlerinin bütün bina mekânlarını ele alan bir tipoloji çalışması bulunmamaktadır. Kat planlarında odaların ve sofanın birbirlerine göre konumları ve odalar arasında yer alan dolu ya da boş, çıkmalı ya da çıkmasız eyvanlar ayrıntılı olarak bu çalışmada ele alınmıştır. Bu çalışmada morfolojik bir yapı ile birlikte kullanıcı ihtiyaçları hiyerarşisine de değinilmeye çalışılmıştır.

Birçok araştırmacının yaptığı gibi bir biçim grameri ortaya koymak hedefinde olmadık. Toplumun sosyal yapısındaki değişiklikler nedeniyle geçmişin biçimlerinin bugünkü koşullarda ele alınıp bilgisayar ortamına aktarılmasının hiç bir anlam taşımadığı kanısındayız. Geçmişin evlerini değerlendirirken, onların içinde bulunduğu toplum
Resim: 8

Paçacıŏlu Konağı'nda ara kata eyvandan giriş.

Resim: 9

Asmazlar Bağ Evi'nde başoda (Bugün otel olarak kullanilmaktadir). 
yapısına göre ihtiyaçlar hiye-rarşisi üzerinde durmayı uygun bulduk. Geçmişin ihtiyaçları ile bugünün ihtiyaçları birbirinden çok farklıdır. Bu da farklı bir yapı tipolojisini gerektirmektedir.

Bugün toplumun aile strüktürü, ekonomik yapısı, kültürel gereksinmeleri tamamıyla değişmiştir. Bu değişim şu anda geleneksel evleri de zorlamaktadır ve yapı morfolojisinde değişiklikleri de beraberinde getirmektedir. Evlerin büyük bir kısmı bugün otel olarak hizmet vermektedir. Geçmişte her bir çekirdek aileye tahsis edilen odalar, bugün otel odası olarak hizmet veren ve yalnız uyuma ve dinlenme gibi temel ihtiyaçların yerine getirildiği mekânlardır

\section{Kaynakça}

Akın, G. 1985. Doğu ve Güneydoğu Anadolu'daki Tarihsel Ev Tiplerinde Anlam. İTÜ Mimarlık Fak. Baskı Atölyesi.

Arel, A. 1982. Osmanlı Konut Geleneğinde Tarihsel Sorunlar. İzmir: EÜ Güzel Sanatlar Fakültesi Yayını.

Bayazıt, N. 1999. Built-In Furniture In the Traditional Turkish Homes: Safranbolu Example. Proceedings of 1st International Furniture Congress and Exhibition. İstanbul, Ekim 14-17 1999.

Bayazıt, N. 2014. Safranbolu Geleneksel Konutları ve Toplumsal Değişme. Safranbolu Belediyesi Safranbolu Araștırmaları Merkezi, Kültür Yayını No: 9. İstanbul: Özlem Matbaacılık ve Reklamcılık Ltd. Şti.

Bulduk, P. 1979. Safranbolu Konutlarının Plan Tipleri. İstanbul: İTÜ MMLS Lisansüstü Tezi.

Eldem, S. H. 1955. Türk Evi Plan Tipleri: İstanbul. İstanbul Teknik Üniversitesi Mimarlık Fakültesi. İstanbul: Pulhan Matbaası.

Eldem, S. H. 1977. Köceoğlu Yalısı Bebek Boğaziçi. Istanbul

Günay, R. 1981. Geleneksel Safranbolu Evleri ve Olușumu, İÜ Edebiyat Fakültesi, Sanat Tarihi ve Estetik Kürsüsü, 1981. Doktora Tezi.

Günay, R. 1999. Türk Evi Geleneği ve Safranbolu Evleri.. İstanbul: YEM Yayınevi.

Günay, R. 2003. Safranbolu Evleri. İstanbul: YEM Yayınevi.

Kıray, Mübeccel B. 1982a. Safranbolu’da Konut İçi Yaşam Olanakları Sınırlamaları ve Turizm Yönü. (İçinde M Kıray) Toplum Bilim Yazıları. der. Kıray, M. Ankara: Gazi Üniversitesi İktisadi ve idari Bilimler Fakültesi, Yayın No: 7 s 389-426

Kıray, Mübeccel B. 1982b. Toplumsal Yapı Analizleri için bir Çerçeve. Toplum Bilim Yazıları. der. Kıray, M. Ankara: Gazi Üniversitesi İktisadi ve idari Bilimler Fakültesi, Yayın No: 7, s 11-19.
Kıray, Mübeccel. 1998. Değişen Toplum Yapısı. İstanbul: Bağlam Yayınları.

Kuban, Doğan. 1975. Türk Evi Geleneği Üzerine Bazı Gözlemler. Sanat Tarihimizin Sorunları, İstanbul

Kuban, Doğan. 1976. Safranbolu'yu Niye Korumalı. TTOK Belleteni. No 54/333, Haziran-Ağustos s. 3-5.

Kuban, Doğan. 1979. Asmazlar Konağı Restorasyon Projesi, Safranbolu. Çevre 3, s. 35-59.

Kuban, Doğan. Türk "Hayat”lı Evi. İstanbul: Eren Yayıncılık ve Kitapçılık Ltd. Ști. 1995.

Kuş, A. 2003. Türkiye'de Mimarlık Değerlerinin Korunmasında ilk Adımlar: Safranbolu 19751980. Safranbolu Kaymakamlığı Hizmet Birliği Yayını.

Meşhur, F. 1979. Safranbolu Konutlarında Oda Tipleri. İTÜ Mimarlık Fakültesi, MMLS Tezi

Nayır, Z. 2011. Safranbolu. Cultural Heritage of Turkey. Ministry of Culture and Tourism Publications. s 184-192.

Sezer, L. 1979. A Conservation Proposal in Safranbolu, Ankara: ODTÜ. (Yayınlanmamış Tez).

Tanyeli, Uğur. 1996. Anadolu'da Bizans Osmanlı Öncesi ve Osmanlı Dönemlerinde Yerleşme ve Barınma Düzeni. Tarihten Günümüz Anadolu'da Konut ve Yerleşme. der. Sey, Y. İstanbul: Türkiye Ekonomik ve Toplumsal Tarih Vakfı.

Ulukavak, K. 2007. Bir Safranbolulunun Penceresinden Safranbolu (Gözlemler-Derlemeler-Denemeler) Ankara: Bizim Büro Basımevi, Yay. Dağ. Tic. Ltd. Şti. 